Article

\title{
Evaluation of Trace Elements in Augmentation of Statin-Induced Cytotoxicity in Uremic Serum-Exposed Human Rhabdomyosarcoma Cells
}

\author{
Hitoshi Uchiyama ${ }^{1}\left(\mathbb{D}\right.$, Masayuki Tsujimoto ${ }^{2, *(\mathbb{D})}$, Naomi Shimada ${ }^{2}$, Koji Tsutsui $^{2}$, Ayaka Nitta ${ }^{2}$, \\ Takuya Yoshida ${ }^{2,3}$, Taku Furukubo ${ }^{3}$, Satoshi Izumi ${ }^{3}$, Tomoyuki Yamakawa ${ }^{4}$, Hidehisa Tachiki ${ }^{1}$, \\ Tetsuya Minegaki ${ }^{2}$ and Kohshi Nishiguchi ${ }^{2}$ \\ 1 Research \& Development Division, Towa Pharmaceutical Co., Ltd., Kyoto Research Park KISTIC\#202, \\ 134 Chudoji Minami-Machi, Shimogyo-ku, Kyoto 600-8813, Japan; h-uchiyama@towayakuhin.co.jp (H.U.); \\ h-tachiki@towayakuhin.co.jp (H.T.) \\ 2 Department of Clinical Pharmacy, Faculty of Pharmaceutical Science, Kyoto Pharmaceutical University, \\ 5 Misasagi Nakauchi-cho, Yamashina-ku, Kyoto 607-8414, Japan; ky09173@poppy.kyoto-phu.ac.jp (N.S.); \\ ky09225@poppy.kyoto-phu.ac.jp (K.T.); ky09267@poppy.kyoto-phu.ac.jp (A.N.); \\ kd13007@poppy.kyoto-phu.ac.jp (T.Y.); t-minegaki@mb.kyoto-phu.ac.jp (T.M.); \\ kohshi@mb.kyoto-phu.ac.jp (K.N.) \\ 3 Department of Pharmacy Service, Shirasagi Hospital, 7-11-23 Kumata, Higashisumiyoshi-ku, \\ Osaka 546-0002, Japan; furukubo@shirasagi-hp.or.jp (T.F.); izumi@shirasagi-hp.or.jp (S.I.) \\ 4 Department of Medicine, Shirasagi Hospital, 7-11-23 Kumata, Higashisumiyoshi-ku, Osaka 546-0002, Japan; \\ yamakawa@shirasagi-hp.or.jp \\ * Correspondence: tsujimt@mb.kyoto-phu.ac.jp; Tel.: +81-75-595-4628
}

Received: 29 November 2017; Accepted: 23 January 2018; Published: 25 January 2018

\begin{abstract}
Patients with end-stage kidney disease (ESKD) are at higher risk for rhabdomyolysis induced by statin than patients with normal kidney function. Previously, we showed that this increase in the severity of statin-induced rhabdomyolysis was partly due to uremic toxins. However, changes in the quantity of various trace elements in ESKD patients likely contribute as well. The purpose of this study is to determine the effect of trace elements on statin-induced toxicity in rhabdomyosarcoma cells exposed to uremic serum (US cells) for a long time. Cell viability, apoptosis, mRNA expression, and intracellular trace elements were assessed by viability assays, flow cytometry, real-time RT-PCR, and ICP-MS, respectively. US cells exhibited greater simvastatin-induced cytotoxicity than cells long-time exposed with normal serum (NS cells) (non-overlapping 95\% confidence intervals). Intracellular levels of $\mathrm{Mg}, \mathrm{Mn}, \mathrm{Cu}$, and $\mathrm{Zn}$ were significantly less in US cells compared to that in NS cells $(p<0.05$ or 0.01 ). Pre-treatment with TPEN increased simvastatin-induced cytotoxicity and eliminated the distinction between both cells of simvastatin-induced cytotoxicity. These results suggest that $\mathrm{Zn}$ deficiencies may be involved in the increased risk for muscle complaints in ESKD patients. In conclusion, the increased severity of statin-induced rhabdomyolysis in ESKD patients may be partly due to trace elements deficiencies.
\end{abstract}

Keywords: end-stage kidney disease; uremic serum; simvastatin; cytotoxicity; zinc; rhabdomyolysis

Key contribution: Our results highlighted deficiencies of various trace elements such $\mathrm{Mg}, \mathrm{Mn}, \mathrm{Cu}$, and $\mathrm{Zn}$ are potential cause of the increased statin-induced cytotoxicity in ESKD patients.

\section{Introduction}

3-Hydroxy-3-methylglutaryl coenzyme A reductase inhibitors (statins), which are potent inhibitors of cholesterol biosynthesis, are widely used for the prevention of atherosclerotic 
cardiovascular disease due to hypercholesterolemia [1-3]. However, statins are associated with a variety of muscle complaints such as myopathies and rhabdomyolysis. Although Strippoli et al. reported that the adverse drug reaction profile of statins was similar to that of placebo in patients with chronic kidney disease [4], rhabdomyolysis is a rare adverse drug reaction and statin-induced rhabdomyolysis was partly regarded as problematic in patients with end-stage kidney disease (ESKD). It is thought that one of the risk factors for rhabdomyolysis among statin users may be, while not statistically significant, kidney dysfunction [5]. The frequency of rhabdomyolysis in ESKD patients may be higher than that in patients with normal kidney function. Recently, we reported that uremic toxins accumulated in ESKD patients is, at least in part, associated with enhancement of statin-induced cytotoxicity via small G-protein geranylgeranylation [6]. In statin users, severe vitamin D deficiency that occurs in ESKD patients also appear to be one of risk factors for myalgia which is an initial symptom of rhabdomyolysis $[7,8]$. These facts indicate that various factors is associated with risk enhancement of statin-induced rabdomyolysis. Despite that, however, the quantity of various trace elements such as $\mathrm{Zn}$ is also changed in ESKD patients [9], it has not been investigated the effects of the difference of trace elements on statin-induced rabdomyolysis.

There is an imbalance of various trace elements, such as low plasma concentrations of $\mathrm{Zn}$, in ESKD patients. In addition, patients undergoing hemodialysis (HD patients) have abnormally high plasma $\mathrm{Cu} / \mathrm{Zn}$ ratios, low activity of superoxide dismutase (SOD), and high levels of oxidative stress; $\mathrm{Zn}$ supplementation in HD patients ameliorates $\mathrm{Cu} / \mathrm{Zn}$ ratios and may reduce oxidative stress [10]. Atorvastatin is associated with mitochondrial reactive oxygen species (ROS)-induced apoptosis in glycolytic skeletal muscle and may contribute to myopathy [11]. Moreover, it has been shown that Zn deficiency induces apoptosis in a variety of tissues in rats [12], and pre-treatment with either $\mathrm{Cu}$ or $\mathrm{Zn}$ reduces growth inhibition by lovastatin in human cervical carcinoma HeLa cells [13]. Therefore, we hypothesized that the concentrations of various trace elements, such as Zn, may be changed in ESKD patients and may augment statin-induced cytotoxicity in striated muscle.

The aim of this study is to determine whether variation in the concentration of trace elements affects statin-induced cytotoxicity. Therefore, we investigated the effects of $\mathrm{Mg}, \mathrm{Ca}, \mathrm{Mn}, \mathrm{Cu}$, and $\mathrm{Zn}$ on statin-induced cytotoxicity in long-time uremic serum (US)-exposed human rhabdomyosarcoma (RD) cells.

\section{Results}

\subsection{Simvastatin, Losartan, or Cisplatin-Induced Cytotoxicity in Serum-Exposed Cells}

The survival curve for US cells was shifted to the left in response to simvastatin, and the $\mathrm{LC}_{50}$ value of simvastatin treated US cells was significantly decreased compared to that of normal serum (NS) cells (Table 1). In contrast, the survival curve for US cells was shifted to the right in response to losartan and cisplatin, and the $\mathrm{LC}_{50}$ values of US cells treated with losartan and cisplatin were significantly increased compared to those of NS cells (Table 1).

Table 1. Lethal concentration $50\left(\mathrm{LC}_{50}\right)$ values for simvastatin, losartan, and cisplatin in serum-exposed cells.

\begin{tabular}{cccc}
\hline \multirow{2}{*}{ Cell Type } & \multicolumn{3}{c}{ LC $_{50}$ Value $(95 \%$ Confidence Interval) } \\
\cline { 2 - 4 } & Simvastatin $(\mu \mathbf{M})$ & Losartan $(\mu \mathrm{M})$ & Cisplatin $(\mu \mathrm{M})$ \\
\hline NS cells & $6.15(5.78-6.73)$ & $582(569-596)$ & $51.1(48.2-54.0)$ \\
US cells & $3.67(3.19-4.15) *$ & $764(735-793) *$ & $64.2(60.6-67.9) *$ \\
\hline
\end{tabular}

Non-overlapping 95\% confidence intervals; * vs. NS cells; Data determined by CellQuanti-Blue ${ }^{\mathrm{TM}}$ Cell Viability Assay Kits represent the mean $(n=4)$. 


\subsection{Simvastatin-Induced Apoptosis in Serum-Exposed Cells}

The number of apoptotic cells in US and NS cells was not different in the non-treatment condition, but apoptosis in US cells treated with simvastatin was greater than that in NS cells (Figure 1).

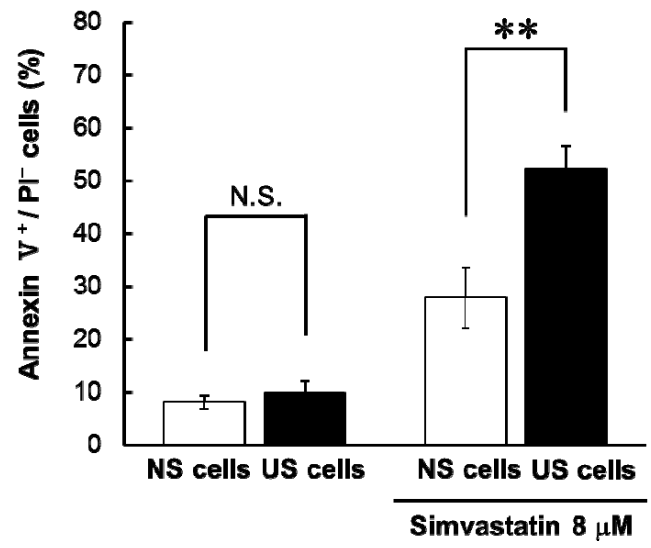

Figure 1. Simvastatin-induced apoptosis in serum-exposed cells. Serum-exposed cells were seeded at $1.5 \times 10^{5}$ cells/well into six-well multiplates. After three days, the medium was changed to the differentiation medium. After seven days, the cells were incubated with the differentiation medium containing $8 \mu \mathrm{M}$ simvastatin for $24 \mathrm{~h}$. Simvastatin-induced apoptosis was determined using flow cytometry with Annexin V/propidium iodide (PI) double staining. Each column represents the mean \pm S.D. $\quad(n=3)$. Significant differences between normal serum (NS) and uremic serum (US)-exposed cells (NS and US cells) were determined using an unpaired Student's $t$-test $(* * p<0.01$, N.S.: not significant). White column: NS cells; black column: US cells.

\subsection{Intracellular Trace Elements in Serum-Exposed Cells}

The intracellular concentrations of Ca in NS and US cells were not different, whereas the intracellular concentrations of $\mathrm{Mg}, \mathrm{Mn}, \mathrm{Cu}$, and $\mathrm{Zn}$ were significantly lower in US cells than in NS cells (Figure 2).

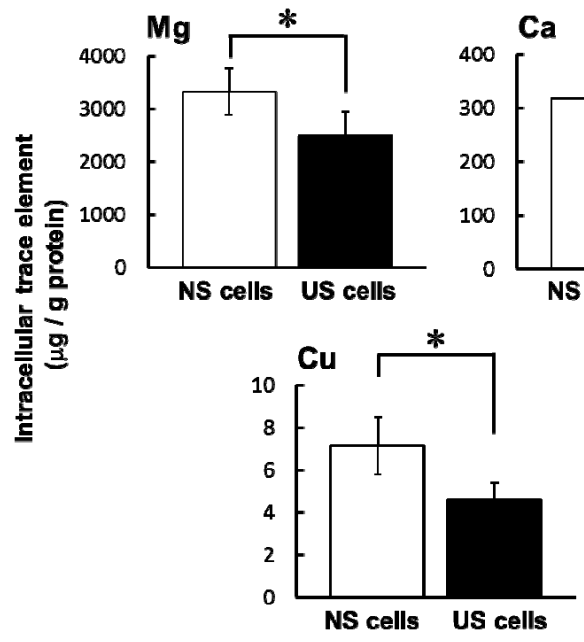

N.S.
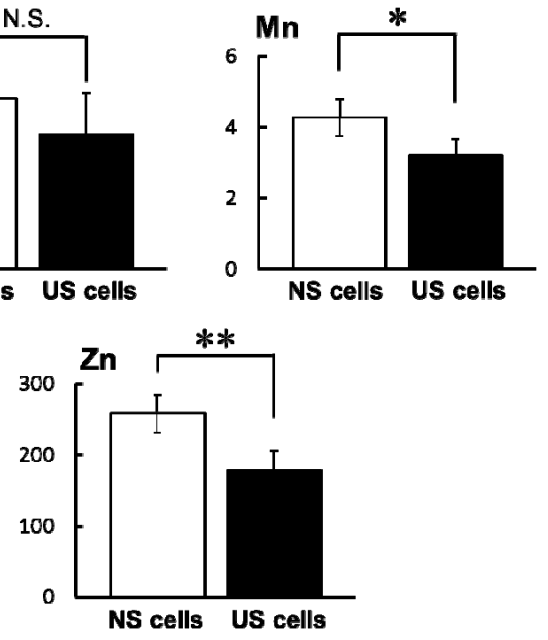

Figure 2. Comparison of intracellular trace elements in serum-exposed cells. Serum-exposed cells were seeded at $3.3 \times 10^{5}$ cells $/$ dish into a $60-\mathrm{mm}$ dish. After four days, the medium was changed to the differentiation medium for seven days. Intracellular concentrations of $\mathrm{Mg}, \mathrm{Ca}, \mathrm{Mn}, \mathrm{Cu}$, and $\mathrm{Zn}$ were evaluated by inductively coupled plasma-mass spectrometry (ICP-MS). Each column represents the mean \pm S.D. $(n=3-4)$. Significant differences between NS and US cells were determined using an unpaired Student's t-test ( $p<0.05,{ }^{* *} p<0.01$, N.S.: not significant). White column: NS cells; black column: US cells. 


\subsection{Pre-Treatment with TPEN Decreases the Level of Intracellular Trace Elements in Serum-Exposed Cells}

Intracellular concentrations of $\mathrm{Mg}, \mathrm{Cu}$, and $\mathrm{Zn}$ in US and NS cells were significantly decreased by pre-treatment with TPEN $\left(N, N, N^{\prime}, N^{\prime}\right.$-tetrakis (2-pyridylmethyl) ethylenediamine) compared to untreated controls (Figure 3).
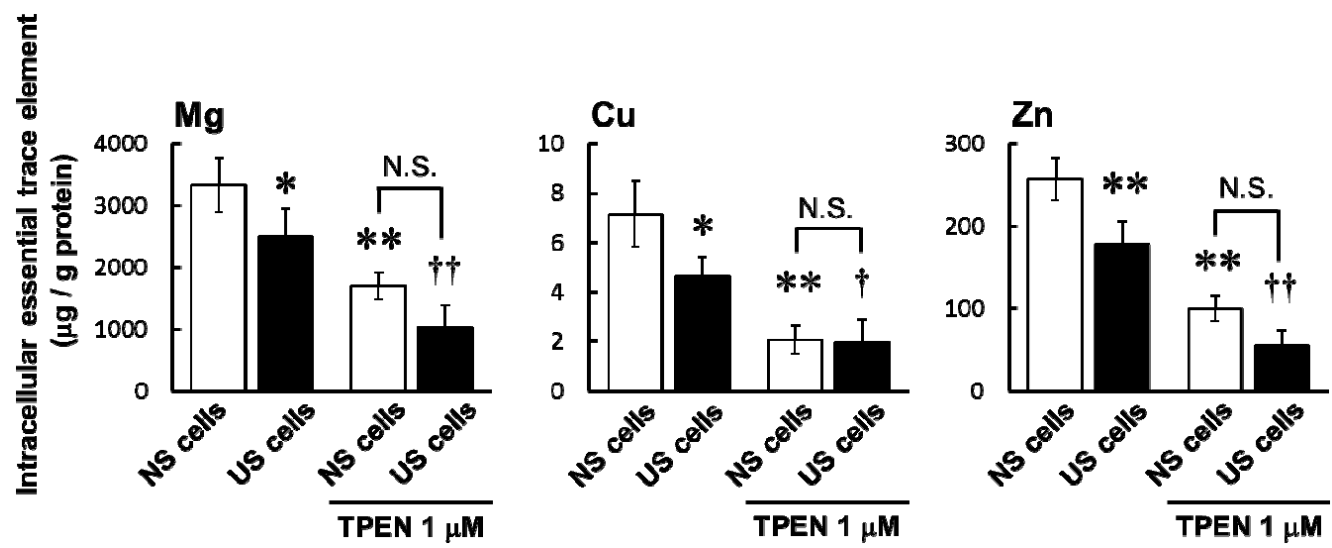

Figure 3. Effects of $N, N, N^{\prime}, N^{\prime}$-tetrakis (2-pyridylmethyl) ethylenediamine (TPEN) on intracellular trace elements in serum-exposed cells. Serum-exposed cells were seeded at $3.3 \times 10^{5}$ cells $/$ dish into $60 \mathrm{~mm}$ dishes. After four days, the medium was changed to the differentiation medium in the presence or absence of TPEN $1 \mu \mathrm{M}$ and incubated for seven days. Intracellular concentrations of $\mathrm{Mg}, \mathrm{Cu}$, and $\mathrm{Zn}$ were evaluated by ICP-MS. Each column represents the mean \pm S.D. $(n=3-4)$. Significant differences were determined by Tukey-Kramer test $\left(^{*} p<0.05,{ }^{* *} p<0.01\right.$ vs. untreated NS cells, ${ }^{\dagger} p<0.05$, ${ }^{+\dagger} p<0.01$ vs. untreated US cells, N.S.: not significant). White column: NS cells; black column: US cells.

\subsection{Pre-Treatment with TPEN Increased Simvastatin-Induced Cytotoxicity in Serum-Exposed Cells}

Pre-treatment with TPEN significantly increased simvastatin-induced cytotoxicity in both US and NS cells, and pre-treatment with TPEN suppressed the augmentation of simvastatin-induced cytotoxicity caused by US (Figure 4 and Table 2).

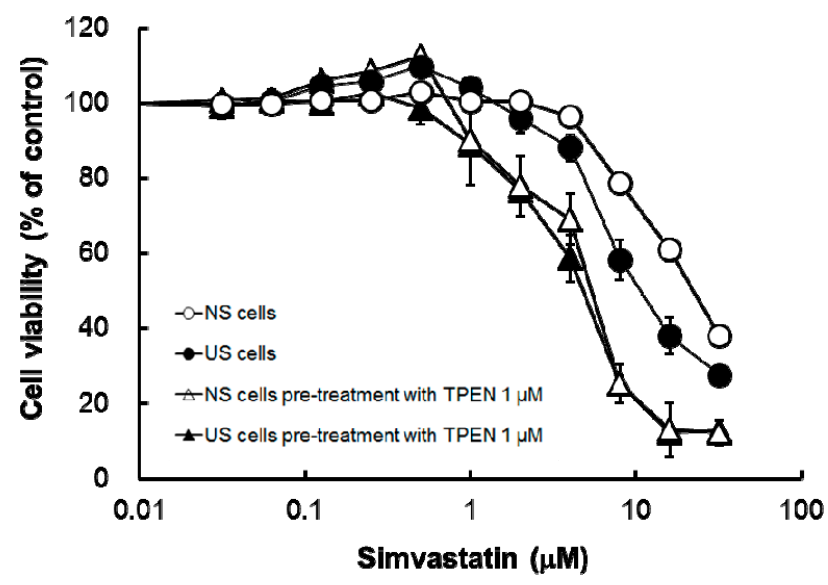

Figure 4. Effects of TPEN on simvastatin-induced cytotoxicity in serum-exposed cells. Serum-exposed cells were seeded at $5 \times 10^{3}$ cells/well into 96-well multiplates. After three days, the medium was changed to the differentiation medium in the presence or absence of TPEN $1 \mu \mathrm{M}$. After seven days, the cells were incubated with the differentiation medium containing simvastatin at various concentrations for three days. The cytotoxicity of simvastatin was determined by CellQuanti-Blue ${ }^{\mathrm{TM}}$ Cell Viability Assay Kits. Each point represents the mean \pm S.D. $(n=4)$. Open circles: NS cells; closed circles: US cells; open triangles: NS cells pre-treatment with TPEN $1 \mathrm{mM}$; closed triangles: US cells pre-treatment with TPEN $1 \mu \mathrm{M}$. 
Table 2. $\mathrm{LC}_{50}$ values for simvastatin in serum-exposed cells with or without TPEN

\begin{tabular}{cc}
\hline \multirow{2}{*}{ Cell Type } & LC $_{\mathbf{5 0}}$ Value $(\mathbf{9 5} \%$ Confidence Interval) \\
\cline { 2 - 2 } & Simvastatin $(\mu \mathrm{M})$ \\
\hline NS cells & $21.61(20.50-22.71)$ \\
NS cells + TPEN 1 $\mu \mathrm{M}$ & $4.75(4.06-5.43){ }^{*}$ \\
US cells & $11.25(10.11-12.39)^{*}$ \\
US cells + TPEN 1 $\mu \mathrm{M}$ & $4.46(4.09-4.84)^{\dagger}$
\end{tabular}

Non-overlapping 95\% confidence intervals; ${ }^{*}$ vs. NS cells; ${ }^{\dagger}$ vs. US cells; Data determined by CellQuanti-Blue ${ }^{\mathrm{TM}}$ Cell Viability Assay Kits represent the mean $(n=4)$.

\section{6. mRNA Expression of Antioxidant Enzymes and a Metal Transporter in Serum-Exposed Cells}

The mRNA expression level of SOD2 was significantly higher in US cells than in NS cells, and that of metallothionein (MT) 1A was significantly lower in US cells than in NS cells. In contrast, the mRNA level of SOD1, MT2A, and glutathione peroxidase 1 (GPx1) were not significantly different in US and NS cells (Figure 5).

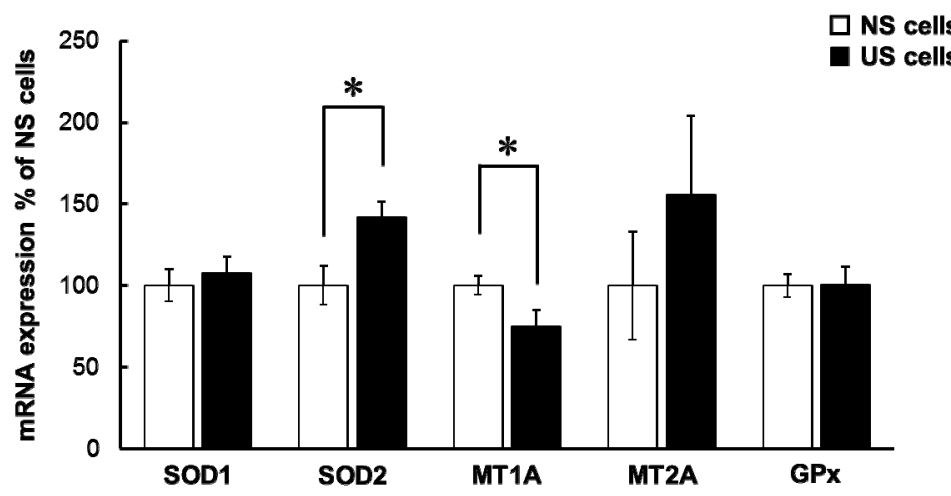

Figure 5. Expression of antioxidant enzymes and a metal transporter in US cells. Serum-exposed cells were seeded at $1.5 \times 10^{5}$ cells/well into six-well multiplates. After three days, the medium was changed to the differentiation medium and incubated for seven days. The level of mRNA expression of superoxide dismutase (SOD) 1, SOD2, metallothionein (MT) 1A, MT2A, and glutathione peroxidase (GPx) was evaluated by quantitative real-time reverse transcriptase polymerase chain reaction (RT-PCR). Each column represents the mean \pm S.D. $(n=3)$. Significant differences between NS and US cells were determined by unpaired Student's $t$-test $\left({ }^{*} p<0.05\right)$. White column: NS cells; black column: US cells.

\section{Discussion}

We had previously shown that statin-induced cytotoxicity in differentiated RD cells was augmented by pre-treatment with uremic toxins-hippuric acid, 3-carboxy-4-methyl-5-propyl-2furanpropionate, indole-3-acetic acid, and 3-indoxyl sulfate, whereas cisplatin-induced cytotoxicity was not affected by pre-treatment with uremic toxins [6]. In this study, simvastatin-induced apoptosis and cytotoxicity was greater in US cells than in NS cells (Table 1 and Figure 1), and here, we found that simvastatin-induced cytotoxicity was similarly augmented in US cells. By contrast, cytotoxicity associated with losartan and cisplatin was lower in US cells than NS cells (Table 1). The effect of long-time exposed with US on cisplatin-induced cytotoxicity in RD cells was different from effect of pre-treatment with uremic toxins [6]. It is possible that the decrease in cisplatin-induced cytotoxicity in US cells was due to serum components apart from uremic toxins. Components in US may vary sensitivity to specific drugs, and US components besides uremic toxins may also affect statin-induced cytotoxicity by accelerating drug-induced apoptosis.

One factor that may influence sensitivity to specific drugs in ESKD patients is an imbalance of various trace elements. Intracellular concentrations of $\mathrm{Mg}, \mathrm{Mn}, \mathrm{Cu}$, and $\mathrm{Zn}$ were significantly lower 
in US cells than in NS cells (Figure 2). Ari et al. reported in HD patients that the serum levels of Zn and $\mathrm{Mn}$ were lower but that levels of $\mathrm{Cu}$ and $\mathrm{Mg}$ were higher compared to healthy volunteers [9]. These differences may be influenced by a meal or circadian rhythms in trace elements. A decrease in intracellular $\mathrm{Mg}$ increases potassium secretion by $\mathrm{Mg}$-mediated inhibition of renal outer medullary potassium channel (ROMK). If ROMK in the apical membrane of distal nephron is in $\mathrm{Mg}$ deficiency same as RD cells, it may be one of risk factors for hypokalemia. Then, the hypokalemia can cause rhabdomyolysis [14,15].

Pre-treatment with the membrane-permeable heavy metal chelator TPEN significantly decreased intracellular concentrations of $\mathrm{Mg}, \mathrm{Cu}$, and $\mathrm{Zn}$ in both US and NS cells (Figure 3) and increased simvastatin-induced cytotoxicity (Figure 4 and Table 2). The result of augmentation of simvastatin-induced cytotoxicity eliminated the distinction between cytotoxicity in US and NS cells (Figure 4 and Table 2). In vivo, it has been reported that $\mathrm{Zn}$ is present at active centers of some antioxidant enzymes, such as SOD, and is an important factor against oxidative stress [16]. Atorvastatin was previously shown to induce changes in oxidative stress and to reduce exercise capacities in rats [17]. Therefore, deficiencies of intracellular trace elements, such as $\mathrm{Zn}$, may be involved in the augmentation of oxidative stress. In important fact to HD patients, it has been reported that the serum levels of $\mathrm{Zn}$ is lower compared to healthy volunteers [9], and oxidative product in plasma is higher compared to healthy volunteers [10]. These results suggest that deficiencies in trace elements may also be involved in the augmentation of simvastatin-induced cytotoxicity caused by US.

mRNA levels of SOD1, MT2A, and GPx1 in US cells were comparable to that in NS cells, but the level of SOD2 mRNA in US cells was significantly higher than that in NS cells (Figure 5). In addition, mRNA levels of SOD1 were significantly decreased in NS and US cells treated with TPEN, but no changes in mRNA levels of SOD2 were found (data not shown). Therefore, augmentation of simvastatin-induced cytotoxicity in US cells may be at least partly associated with oxidative stress.

mRNA expression of MT1A in US cells was significantly lower than in NS cells (Figure 5). Metallothioneins are proteins with the capacity to bind metal, and have a function in antioxidation. Hence, alterations in simvastatin-induced cytotoxicity caused by US may be due to the low level of MT1A expression. The level of MT expression was increased by Zn and decreased by TPEN [18], suggesting that decreased levels of MT1A mRNA may be associated with intracellular Zn deficiencies.

The limitations of this study include lack of changes in oxidative stress, and the relationship between protein and mRNA expression levels. Accordingly, typical markers of oxidative stress or ROS production and the protein expression of antioxidant enzymes or a metal transporter need to be measured directly to confirm our findings.

\section{Conclusions}

In this study, we showed that the augmentation of simvastatin-induced cytotoxicity in US cells was caused, in part, by promotion of apoptosis, which resulted from trace element deficiencies such as $\mathrm{Zn}$. The simvastatin-induced cytotoxicity may be alleviated partially by supplementation of trace elements such as $\mathrm{Zn}$. However, further research is needed to confirm this mechanism and effect of variation in other trace elements. Our findings contribute to a growing body of evidence explaining why statin-induced rhabdomyolysis is enhanced in ESKD patients and may lead to more appropriate use of statins in these patients in the future.

\section{Materials and Methods}

\subsection{Chemicals}

Simvastatin was purchased from Toronto Research Chemicals, Inc. (North York, ON, Canada). Losartan was purchased from LKT Laboratories, Inc. (St. Paul, MN, USA). Cisplatin was purchased from Wako Pure Chemical Industries (Osaka, Japan). TPEN was purchased from Santa Cruz Biotechnology, Inc. (Dallas, TX, USA). Annexin V-fluorescein isothiocyante (FITC) was purchased 
from BioLegend, Inc. (San Diego, CA, USA). The Cell Quanti-Blue ${ }^{\mathrm{TM}}$ Cell Viability Assay Kit (CellQuanti-Blue ${ }^{\mathrm{TM}}$ ) was purchased from BioAssay Systems (Hayward, CA, USA). Pooled human serum as NS was purchased from Merck Millipore Co. (Billerica, MA, USA). Serum that was pooled from more than 400 dialysis patients as US was obtained from Shirasagi Hospital (Osaka, Japan). Because the patients were administered various drugs for medication, those drugs might affect our research. All uremic sera, however, were collected from patients just before hemodialysis. Because HD patients do not administer drugs before hemodialysis in general except for prophylactic drug for adverse events such as dialysis hypotension, it was thought that there were negligible effects of prescription drugs in US. This study (approval number 08-04) was approved in advance by the Shirasagi Hospital and Kyoto Pharmaceutical University ethical review board on 11 December 2008 and 1 April 2008, respectively.

\subsection{Cell Culture}

The RD cell line was purchased from American Type Culture Collection (Manassas, VA, USA). Dulbecco's modified Eagle's medium (DMEM, Life Technologies, Tokyo, Japan) without fetal bovine serum (FBS, Thermo Fisher Scientific, Inc., Kanagawa, Japan) contained sodium hydrogen carbonate (3.7 g), $100 \mathrm{U} / \mathrm{mL}$ penicillin, and $100 \mu \mathrm{g} / \mathrm{mL}$ streptomycin and $0.1 \mathrm{mM}$ non-essential amino acids solution (Nacalai Tesque, Inc., Kyoto, Japan). NS and US were deproteinized using three volumes methanol and the supernatants were dried under a stream of nitrogen at $50{ }^{\circ} \mathrm{C}$. The residue was dissolved in 10 volumes DMEM without FBS and ultrafiltered using a $0.22 \mu \mathrm{m}$ membrane filter. The final concentration of $10 \%$ FBS was ultrafiltered in DMEM with serum using a $0.45 \mu \mathrm{m}$ membrane filter, and these media were named 10\% NS medium or 10\% US medium, respectively. RD cells were exposed for at least one month to $10 \%$ NS medium or $10 \%$ US medium at $37{ }^{\circ} \mathrm{C}$ with $5 \% \mathrm{CO}_{2}$. During this period, RD cells were re-plated at a density of $1 \times 10^{6}$ cells per $10 \mathrm{~mL}$ in media every third or fourth day. The resulting cells were named NS and US cells, respectively.

\subsection{Evaluation of Cytotoxicity}

RD cells that grown as the following are a model cells of human skeletal muscle and used for myotoxicity evaluation in this study [19]. NS and US cells were plated at a density of $5 \times 10^{3}$ cells/well/100 $\mu \mathrm{L}$ into 96-well plates in DMEM with $10 \% \mathrm{FBS}$ for three days at $37^{\circ} \mathrm{C}$ with $5 \% \mathrm{CO}_{2}$. These cells were then cultured in DMEM with 1\% FBS (differentiation medium) for seven days to induce differentiation. In the pre-treatment experiment with TPEN, $1 \mu \mathrm{M}$ TPEN was added to the differentiation medium. After removal of the medium from differentiated RD cells, differentiated RD cells were exposed to medium containing the following test compounds for three days at $37^{\circ} \mathrm{C}$ with $5 \% \mathrm{CO}_{2}$. The concentrations of simvastatin, losartan, and cisplatin (test compounds) used were $0.03125-32$ or $0.25-256 \mu \mathrm{M}, 16-4096 \mu \mathrm{M}$, and $0.5-512 \mu \mathrm{M}$, respectively.

After treatment with the test compounds for three days, cell viability was measured using CellQuanti-Blue ${ }^{\mathrm{TM}}$ and a microplate reader (excitation wavelength $=535 \mathrm{~nm}$, emission wavelength $=$ $590 \mathrm{~nm}$, GENios, Tecan, Seestrasse, Switzerland).

The lethal concentration $50\left(\mathrm{LC}_{50}\right)$ value was calculated using the non-linear least squares program (MULTI)

$$
L=L_{\max } \times\left(1-\frac{C^{\gamma}}{C^{\gamma}+L C_{50} \gamma}\right)
$$

where $L, L_{\max }, C$, and $\gamma$ are cell viability (\% of control), maximum cell lethality, drug concentration in the medium, and sigmoid function, respectively.

\subsection{Assessment of Apoptosis}

NS and US cells were incubated in medium containing $8 \mu \mathrm{M}$ simvastatin for $24 \mathrm{~h}$ (shorter than cytotoxicity experiment) at $37^{\circ} \mathrm{C}$ with $5 \% \mathrm{CO}_{2}$. NS and US cells dissociated by trypsin-EDTA were suspended at a concentration of $1 \times 10^{6}$ cells $/ \mathrm{mL}$ in ice-cold buffer $\left(140 \mathrm{mM} \mathrm{NaCl}, 2.5 \mathrm{mM} \mathrm{CaCl}_{2}\right.$, 
10 mM 2-[4-(2-hydroxyetyl)-1-piperazinyl] ethanesulfonic acid (HEPES)/NaOH, pH 7.4). Annexin V-FITC $(5 \mu \mathrm{L})$ and $50 \mu \mathrm{g} / \mathrm{mL}$ propidium iodide (PI) solution $(1 \mu \mathrm{L})$ were added to the $100 \mu \mathrm{L}$ cell suspension and incubated for $15 \mathrm{~min}$ in the dark. The reaction solution was diluted five-fold in the same buffer and then analyzed using fluorescence activated cell sorting (FACS) Calibur ${ }^{\mathrm{TM}}$ (Becton Dickinson, Franklin Lakes, NJ, USA). Apoptotic cells were defined as those that were annexin V-FITC-positive and PI-negative.

\subsection{Measurement of Intracellular Trace Elements}

NS and US cells were lysed by addition of $1 \%$ sodium dodecyl sulfate $(5 \mathrm{~mL})$. After pouring the cell lysate $(4.7 \mathrm{~mL})$ into a nitric acid-treated tall beaker, the lysate was evaporated completely on a hot plate at $170{ }^{\circ} \mathrm{C}$. Upon addition, in turn, of nitric acid, perchloric acid, and hydrogen peroxide to the residue, the residue was dried under the same conditions as described above. Three cycles of the same operation were performed for complete incineration of the sample.

The incinerated sample was lysed by addition of nitric acid $(9 \mathrm{~mL})$, and the concentrations of intracellular $\mathrm{Mg}, \mathrm{Ca}, \mathrm{Mn}$, and $\mathrm{Zn}$ were determined by inductively coupled plasma-mass spectrometry (ICP-MS, Agilent 7700, Agilent Technologies Japan, Ltd., Tokyo, Japan). Prepared calibration standard samples were $0,5,10,50,100$, and $500 \mathrm{ppb}$. The overall relationship among the standards was best described by a linear relationship $\left(r^{2}>0.999\right)$.

\subsection{Measurement of $m R N A$}

NS and US cells were lysed by addition of RNAzol ${ }^{\circledR}$ RT Reagent $(1 \mathrm{~mL}$, Molecular Research Center, Inc., Cincinnati, OH, USA). After adding diethyl pyrocarbonate-treated water $(400 \mu \mathrm{L})$ to the cell lysates, they were vortex mixed for $15 \mathrm{~s}$, left at room temperature for $15 \mathrm{~min}$, and centrifuged at $12,000 \times g$ at $25^{\circ} \mathrm{C}$ for $15 \mathrm{~min}$. After adding isopropanol $(1 \mathrm{~mL})$ to the supernatant $(1 \mathrm{~mL})$, the supernatant was left at room temperature for $10 \mathrm{~min}$. RNA precipitate formed a pellet upon centrifugation at $12,000 \times g$ at $25{ }^{\circ} \mathrm{C}$ for $15 \mathrm{~min}$. The residue was removed from the supernatant and was washed twice using $75 \%$ ethanol $(500 \mu \mathrm{L})$. After washing, RNase-free water $(50 \mu \mathrm{L})$ was added to the residue, and the RNA in the residue was quantified spectrophotometrically at $260 \mathrm{~nm}$ using a DU ${ }^{\circledR} 730$ (Becton Dickinson). RNA quantity was calculated using the formula

$$
\text { RNA quantity }(\mu \mathrm{g} / \mathrm{mL})=\mathrm{A}_{260} \times 40
$$

The RNA solutions were diluted to $100 \mu \mathrm{g} / \mathrm{mL}$ with RNase-free water and stored at $-80{ }^{\circ} \mathrm{C}$.

Reverse transcriptase polymerase chain reaction (RT-PCR) was performed using ReverTra Ace ${ }^{\circledR}$ qPCR (Toyobo, Ltd., Osaka, Japan). For preparation of cDNA, the total reaction volume per sample was $20 \mu \mathrm{L}(9 \mu \mathrm{L}$ of nuclease-free water, $4 \mu \mathrm{L}$ of $5 \times$ RT buffer, $1 \mu \mathrm{L}$ of RT enzyme mix, $1 \mu \mathrm{L}$ of primer mix, $5 \mu \mathrm{L}$ of RNA). RT-PCR was performed using an i-Cycler iQ (Bio-Rad Laboratories, Inc., Hercules, $\mathrm{CA}, \mathrm{USA}$ ) with $37^{\circ} \mathrm{C}$ for $15 \mathrm{~min}$ (reverse transcription reaction), $98^{\circ} \mathrm{C}$ for $5 \mathrm{~min}$ (inactivation of reverse transcriptase), and then $4{ }^{\circ} \mathrm{C}$ (cooling). DNA was amplified in a total reaction solution volume of $20 \mu \mathrm{L}$ (7.16 $\mu \mathrm{L}$ of sterile distilled water, $10 \mu \mathrm{L}$ of Thunderbird ${ }^{\mathrm{TH}} \mathrm{SYBR}^{\circledR} \mathrm{qPCR}^{\circledR}$ ix (Toyobo), $0.4 \mu \mathrm{L}$ of $10 \mu \mathrm{M}$ sense primer, $0.4 \mu \mathrm{L}$ of $10 \mu \mathrm{M}$ antisense primer, $0.04 \mu \mathrm{L}$ of $50 \times$ ROX reference dye (Toyobo), $2 \mu \mathrm{L}$ of RT sample). Real-time PCR was performed using a LightCycler ${ }^{\circledR}$ Nano System (Roche Diagnostics K.K., Tokyo, Japan). The initial denaturation was $95^{\circ} \mathrm{C}$ for $1 \mathrm{~min}$ and was followed by 45 cycles of amplification, with a thermal cycling profile of $95^{\circ} \mathrm{C}$ for $10 \mathrm{~s}$ and $60{ }^{\circ} \mathrm{C}$ for $30 \mathrm{~s}$. Beta-2-microglobulin $(\beta 2 \mathrm{M})$ was used as a housekeeping gene. Primer sequences are specified in Table 3.

$\mathrm{C}_{\mathrm{T}}$ was calculated using the fluorescence intensity of $S Y B R^{\circledR}$ Green $\mathrm{I}$, and the amount of target mRNA relative to $\beta 2 \mathrm{M}$ mRNA was expressed as $2^{-\Delta \mathrm{CT}}$, where $\Delta \mathrm{C}_{\mathrm{T}}$ is the value obtained by subtracting the $C_{T}$ value of $\beta 2 M$ mRNA from the $C_{T}$ value of the target mRNA. 
Table 3. Sequences of primers used to amplify different genes by real-time PCR.

\begin{tabular}{cc}
\hline Gene (PCR Products Size) & Sequences \\
\hline SOD1 (174 b.p.) & $\begin{array}{c}\text { Sense 5'-GAA GGT GTG GGG AAG CAT TA-3' } \\
\text { Antisense 5'-ACA TTG CCC AAG TCT CCA AC-3' }\end{array}$ \\
\hline SOD2 (313 b.p.) & $\begin{array}{r}\text { Sense 5'-CGT CAC CGA GGA GAA GTA CC-3' } \\
\text { Antisense 5'-CTG ATT TGG ACA AGC AGC AA-3' }\end{array}$ \\
\hline MT1A (156 b.p.) & $\begin{array}{c}\text { Sense 5'-ACT GGT GGC TCC TGC ACC TGC ACT-3' } \\
\text { Antisense 5'-ACA GCA GCT GCA CTT CTC TGA T-3' }\end{array}$ \\
\hline MT2A (259 b.p.) & $\begin{array}{c}\text { Sense 5'-CCG ACT CTA GCC GCCTCT T-3' } \\
\text { Antisense 5'-GTG GAA GTC GCG TTC TTT ACA-3' }\end{array}$ \\
\hline GPx1 (85 b.p.) & $\begin{array}{c}\text { Sense 5'-CCA AGC TCA TCA CCT GGT CT-3' } \\
\text { Antisense 5'-TCG ATG TCA ATG GTC TGG AA-3' }\end{array}$ \\
\hline B2M (313 b.p.) & $\begin{array}{c}\text { Sense 5'-TGC TCG CGC TAC TCT CTC TTT-3' } \\
\text { Antisense 5'-TTC TCT GCT TGA CGT GAG TAA-3' }\end{array}$ \\
\hline
\end{tabular}

\subsection{Statistical Analysis}

Measured values and $\mathrm{LC}_{50}$ values were expressed as mean \pm standard deviation (S.D.) and median (95\% confidence intervals), respectively. Non-overlapping confidence intervals of $\mathrm{LC}_{50}$ were considered statistically significant. The significant differences between groups were determined using unpaired Student's $t$-test or non-repeated measures analysis of variance (ANOVA) followed by Tukey-Kramer multiple comparison test. A $p$ value less than 0.05 was considered statistically significant.

Acknowledgments: Funds for this study were provided by a grant from the Ministry of Education, Culture, Sports, Science and Technology of Japan (MEXT)-Supported Program for the Strategic Research Foundation at Private Universities, 2012-2016 (S1201008) and by a Grant-in-Aid for Scientific Research (C) (No. 15K08601) from Japan Society for the Promotion of Science.

Author Contributions: All authors participated in the design, interpretation of the study and analysis of the data and review of manuscript. Naomi Shimada, Koji Tsutsui and Ayaka Nitta performed the experiments. Hitoshi Uchiyama and Masayuki Tsujimoto wrote the manuscript.

Conflicts of Interest: The authors declare that they have no conflict of interest.

\section{References}

1. Kim, H.J.; Kim, E.K.; Kwon, S.U.; Kim, J.S.; Kang, D.W. Effect of statin on progression of symptomatic intracranial atherosclerosis. Can. J. Neurol. Sci. 2012, 39, 801-806. [CrossRef] [PubMed]

2. Shah, S.; Paparello, J.; Danesh, F.R. Effects of statin therapy on the progression of chronic kidney disease. Adv. Chronic Kidney Dis. 2005, 12, 187-195. [CrossRef] [PubMed]

3. Shepherd, J.; Cobbe, S.M.; Ford, I.; Isles, C.G.; Lorimer, A.R.; Macfarlane, P.W.; McKillop, J.H.; Packard, C.J. Prevention of coronary heart disaease with pravastatin in men with hypercholesterolemia. N. Engl. J. Med. 1995, 333, 1301-1307. [CrossRef] [PubMed]

4. Strippoli, G.F.; Navaneethan, S.D.; Johnson, D.W.; Perkovic, V.; Pellegrini, F.; Nicolucci, A.; Craig, J.C. Effects of statins in patients with chronic kidney disease: Meta-analysis and meta-regression of randomised controlled trials. BMJ 2008, 336, 645-651. [CrossRef] [PubMed]

5. Schech, S.; Graham, D.; Staffa, J.; Andrade, S.E.; La Grenade, L.; Burgess, M.; Blough, D.; Stergachis, A.; Chan, K.A.; Platt, R.; et al. Risk factors for statin-associated rhabdomyolysis. Pharmacoepidemiol. Drug Saf. 2007, 16, 352-358. [CrossRef] [PubMed]

6. Uchiyama, H.; Tsujimoto, M.; Shinmoto, T.; Ogino, H.; Oda, T.; Yoshida, T.; Furukubo, T.; Izumi, S.; Yamakawa, T.; Tachiki, H.; et al. Uremic toxins enhance statin-induced cytotoxicity in differentiated human rhabdomyosarcoma cells. Toxins 2014, 6, 2612-2625. [CrossRef] [PubMed]

7. Tsujimoto, M.; Nagano, Y.; Hosoda, S.; Shiraishi, A.; Miyoshi, A.; Hiraoka, S.; Furukubo, T.; Izumi, S.; Yamakawa, T.; Minegaki, T.; et al. Effects of decreased vitamin D and accumulated uremic toxin on human CYP3A4 activity in patients with end-stage renal disease. Toxins 2013, 5, 1475-1485. [CrossRef] [PubMed] 
8. Mergenhagen, K.; Ott, M.; Heckman, K.; Rubin, L.M.; Kellick, K. Low vitamin D as a risk factor for the development of myalgia in patients taking high-dose simvastatin: A retrospective review. Clin. Ther. 2014, 36, 770-777. [CrossRef] [PubMed]

9. Ari, E.; Kaya, Y.; Demir, H.; Asicioglu, E.; Keskin, S. The correlation of serum trace elements and heavy metals with carotid artery atherosclerosis in maintenance hemodialysis patients. Biol. Trace Elem. Res. 2011, 144, 351-359. [CrossRef] [PubMed]

10. Guo, C.H.; Wang, C.L. Effects of zinc supplementation on plasma copper/zinc ratios, oxidative stress, and immunological status in hemodialysis patients. Int. J. Med. Sci. 2013, 10, 79-89. [CrossRef] [PubMed]

11. Bouitbir, J.; Singh, F.; Charles, A.L.; Schlagowski, A.I.; Bonifacio, A.; Echaniz-Laguna, A.; Geny, B.; Krahenbuhl, S.; Zoll, J. Statins Trigger Mitochondrial ROS-Induced Apoptosis in Glycolytic Skeletal Muscle. Antioxid. Redox Signal. 2016, 24, 84-89. [CrossRef] [PubMed]

12. Nodera, M.; Yanagisawa, H.; Wada, O. Increased apoptosis in a variety of tissues of zinc-deficient rats. Life Sci. 2001, 69, 1639-1649. [CrossRef]

13. Fowler, M.; Cooper, S.J.; Stephany, J.J.; Hendon, N.; Nelson, S.; Fields, S. Suppression of statin effectiveness by copper and zinc in yeast and human cells. Mol. Biosyst. 2011, 7, 533-544. [CrossRef] [PubMed]

14. Huang, C.L.; Kuo, E. Mechanism of hypokalemia in magnesium deficiency. J. Am. Soc. Nephrol. 2007, 18, 2649-2652. [CrossRef] [PubMed]

15. Lane, R.; Phillips, M. Rhabdomyolysis. BMJ 2003, 327, 115-116. [CrossRef] [PubMed]

16. Hart, P.J.; Balbirnie, M.M.; Ogihara, N.L.; Nersissian, A.M.; Weiss, M.S.; Valentine, J.S.; Eisenberg, D. A structure-based mechanism for copper-zinc superoxide dismutase. Biochemistry 1999, 38, 2167-2178. [CrossRef] [PubMed]

17. Bouitbir, J.; Charles, A.L.; Rasseneur, L.; Dufour, S.; Piquard, F.; Geny, B.; Zoll, J. Atorvastatin treatment reduces exercise capacities in rats: Involvement of mitochondrial impairments and oxidative stress. J. Appl. Physiol. 2011, 111, 1477-1483. [CrossRef] [PubMed]

18. Chung, M.J.; Hogstrand, C.; Lee, S.J. Cytotoxicity of nitric oxide is alleviated by zinc-mediated expression of antioxidant genes. Exp. Biol. Med. 2006, 231, 1555-1563. [CrossRef]

19. Nishimoto, T.; Tozawa, R.; Amano, Y.; Wada, T.; Imura, Y.; Sugiyama, Y. Comparing myotoxic effects of squalene synthase inhibitor, T-91485, and 3-hydroxy-3-methylglutaryl coenzyme A (HMG-CoA) reductase inhibitors in human myocytes. Biochem. Pharmacol. 2003, 66, 2133-2139. [CrossRef] [PubMed] 